Author version: Bioresource Technology, vol.102(3); 2011; 2411-2418

\title{
A novel hybrid technology for remediation of molasses-based raw effluents
}

\author{
Ashutosh Kumar Verma, Chandralata Raghukumar*, Chandrakant Govind Naik \\ National Institute of Oceanography, \\ (A constituent laboratory of Council for Scientific and Industrial Research, New Delhi), \\ Dona Paula, Goa, India-403004 \\ *Corresponding author's email: (lata@nio.org) \\ Fax \# +91 4322450606
}

\begin{abstract}
A novel three-step technology for treatment of four molasses-based raw industrial effluents, varying in their COD, color and turbidity is reported here. Sequential steps involved in this treatment are; 1) sonication of the effluents, 2) whole-fungal treatment of these by a ligninolytic marine fungus and 3) biosorption of the residual color with heat-inactivated biomass of the same fungus. Sonication reduced the foul odor and turbidity of the effluents. It increased biodegradability of the effluents in the second stage of treatment. Laccase production in the presence of all the four effluents was directly correlated with their decolorization. After the third step, a reduction of $60-80 \%$ in color, $50-70 \%$ in COD and $60-$ $70 \%$ in total phenolics were achieved. Comparative mass and nuclear magnetic resonance spectra indicated increasing degradation of the effluent components after each stage. Toxicity ( $\mathrm{LC}_{50}$ values) against Artemia larvae was reduced by two to five folds.

Keywords: molasses-based wastewater, sonication, marine-derived fungus, decolorization, detoxification
\end{abstract}




\section{Introduction}

Wastewaters containing molasses are generated by distilleries, fermentation industries, sugar mills and other molasses-based industries. These contain melanoidin polymers which are the product of Maillard reaction between the amino acids and carbonyl groups in molasses. With their high biochemical and chemical oxygen demand, these effluents are environmental hazards. When released in water bodies they cause oxygen depletion and associated problems, and/or if released in soil they reduce the soil alkalinity and manganese availability, inhibit seed germination and affect vegetation. Besides causing unaesthetic discoloration of water and soil, melanoidin pigments are also toxic to microorganisms present in soil and water (Mohana et al., 2009, Agarwal et al., 2010). Dark brown color of these effluents is highly resistant to microbial degradation and other biological treatments. Anaerobic digestion of effluents produces dark brown sludge which is used as fertilizer and the colored waters are discharged after diluting them several folds with water. Thus ultimately fresh water resource which is a precious commodity in most parts of the world is wasted.

Bioremediation of melanoidin-containing waste waters with white-rot fungi and their lignindegrading enzymes have been reported (Gold and Alic, 1993; Thakker et al., 2006). These ligninolytic enzymes are non-specific in their substrate requirement. Besides degradation of lignin from vascular plants, they are involved in degradation of various recalcitrant compounds such as polychlorinated biphenyls, chlorinated phenolic compounds, polycyclic aromatic hydrocarbons, pesticides and dyes. The extremely wide range of degradative activity is dependent on the lignin-degrading enzymes, lignin peroxidase (LiP), manganese peroxidase (MnP), laccase and $\mathrm{H}_{2} \mathrm{O}_{2}$-producing enzymes (Gold and Alic, 1993). Several bacterial systems have also been reported to decolorize and reduce COD of distillery spent wash (see ref in Mohana et al., 2009). Adsorption through activated carbon or organic resin is the most common practice, in spite of the high costs involved. Biosorption, an alternative to physicochemical treatment is recommended by several researchers for treatment of colored effluents. Live or dead microbial biomass of algae, yeast, bacteria and fungi has been used for this purpose (Satyawali and Balakrishnan, 2008). However, dead microbial biomass is preferred because they do not pose health risk by their presence or their toxins and are in turn not affected adversely by the toxic effluents. Microbial bioadsorbants have been used for removal of heavy metals (Gadd, 2009), dyes (Prigione et al., 2008) and hazardous organic pollutants (Aksu, 2005). The process of biosorption is reported to be governed by type of membrane lipids (Kennedy and Pham, 1995), pH and hydrophilicity (Bayramoğlu and Arica, 2007). 
Another method reported in treatment of industrial and domestic wastewater is application of ultrasound (sonication) which is an advanced oxidation method (Sangave et al., 2007). Sonication causes formation of gaseous bubbles or vaporous cavities in a liquid. These subsequently collapse violently causing increase in temperature and pressure locally at several points in a reactor resulting in the formation of reactive hydrogen atoms and hydroxyl radicals. These two combine to form hydrogen peroxide which promotes oxidation reactions and is responsible for the destruction of refractory compounds. Sonication is generally performed as a pre-oxidation step before biological treatment as it is reported to increase biodegradability (Sangave and Pandit 2006). However, its effect on decolorization of industrial effluents has not been reported.

Individually, these methods of treatment have their limitations and therefore, a combined approach was attempted on laboratory scale. This paper describes a three-step sequential treatment of four molasses-based raw effluents using a combination of 1) ultrasound-induced acoustic cavitation, 2) whole fungal culture-treatment using the marine-derived ligninolytic fungus, NIOCC \#2a followed by, 3) biosorption of the residual color with heat-inactivated wet biomass of the same fungus. Bioremediation was monitored after each step by estimating reduction in color, COD and phenolics and detoxification by toxicity test with brine shrimp Artemia as a test organism. Spectrophotometric and mass spectrometric analyses after each step of treatment were also carried out to follow degradation and transformation of the effluents.

\section{Material and Methods}

\subsection{Waste Water}

Four molasses-based raw effluents were used for this study (Table 1). Reverse Osmosis Feed (ROF) and Reverse Osmosis Reject (ROR) were provided by Jeypore Sugar Co. Ltd., Chagallu, Andhra Pradesh, India. Conventional aeration tank inlet (CAT I) and Conventional aeration tank outlet (CAT O) were provided by the Emmellen Biotech Pharmaceuticals Ltd., Mahad, Maharashtra, India.

\subsection{Physico-chemical analyses of waste waters}

All the four effluents were centrifuged at $8000 \mathrm{rpm}$ for 15 minutes before further analysis. The analysis for different physico-chemical parameters of waste waters was accomplished (Table 1) as described in standard methods for examination of water and wastewater (APHA, AWWA, WEF, 2005). The effluents were stored at $4^{\circ} \mathrm{C}$ in the dark. The working concentration of these effluents was adjusted to $\mathrm{A}_{475}=3.5$. 


\subsection{Sonication and analysis of the effluents}

Sonication was carried out using ultrasonic horn (Labsonic M, Sartorius, Germany) with an operational frequency of $30 \mathrm{kHz}$ and calorimetric energy efficiency of $600 \mathrm{M} \mathrm{cm}^{-2}$. Sonication of the effluents (40 ml in $100 \mathrm{ml}$ Schott Duran bottle) was carried out for $30 \mathrm{~min}$ at $100 \%$ amplitude using a 2 $\mathrm{mm}$ titanium probe. Sonicated effluents were analysed for the reduction in turbidity, color, COD, total phenolics and toxicity. Absorbance spectra $(200-800 \mathrm{~nm})$ of the effluents before and after sonication were compared.

\subsection{Test Organism and culture conditions}

The basidiomycetous fungus NIOCC \#2a isolated from decaying mangrove wood was maintained on Boyd and Kohlmeyer (B \& K) agar medium (Kohlmeyer and Kohlmeyer, 1979) containing $1 \%$ glucose, $0.2 \%$ peptone, $0.1 \%$ yeast extract and $1.5 \%$ agar in half-strength sea water with salinity of 15 $17 \mathrm{psu}$ (practical salinity units) and was routinely checked for purity by light microscopy. The fungus is deposited in the Microbial Type culture Collection (MTCC, Chandigarh, India) under the accession No. MTCC 5159 as per the Budapest treaty for patent culture deposition (D'Souza et al., 2006). The fungus showed $99 \%$ homology to Cerrena unicolor by sequence analysis of $18 \mathrm{~S}$ rDNA region (Verma et al., 2010).

\subsection{Decolorisation by the whole fungal culture and partially purified laccase}

The white-rot fungus was grown in B \& $\mathrm{K}$ broth $(20 \mathrm{ml}$ in $100 \mathrm{ml}$ Erlenmeyer flasks) for 7 days. The fungal biomass after rinsing to remove the residual medium was homogenized in sterile sea water in Omni Macrohomogenizer (No.17505, Marietta, GA, USA) for $5 \mathrm{~s}$. The mycelial suspension $(10 \%$, v/v) was used for inoculating $20 \mathrm{ml}$ of low nitrogen (LN) medium (D'Souza-Ticlo et al., 2006). After six days of growth under stationary condition, unsonicated and sonicated effluent as specified in the section 2.3 were added to the culture broth under aseptic condition. Before addition the $\mathrm{pH}$ of the effluents was adjusted to 5.0 with $0.1 \mathrm{M}$ sodium acetate buffer. Decolorization of the effluents in the culture supernatants was monitored at $475 \mathrm{~nm}$ after appropriately diluting with $0.1 \mathrm{M}$ sodium acetate buffer at pH 5.0 (Ohmomo et al., 1988) on day 0,3,6 and 9. Decrease in absorbance with respect to that of abiotic control was used for calculating $\%$ decolorization. Triplicate cultures were maintained for each treatment. The fungal biomass was collected on day 9 after centrifugation of the culture at $5000 \mathrm{rpm}$ for $10 \mathrm{~min}$ and was washed twice with distilled water to remove the salts. It was lyophilized and the dry 
weight was estimated. The difference between the biomass without and with effluents was calculated in percentage.

In vitro decolorization was performed using partially purified laccase. Culture filtrate (500 ml) from 12-day old culture of NIOCC \#2a was concentrated with YM3 membrane (Millipore, USA). The concentrate after filtering through a $0.22 \mu \mathrm{m}$ filter was applied to High Load 16/60 Superdex 75 preparative grade column and eluted with $0.2 \mathrm{M} \mathrm{Na}$ acetate buffer $(\mathrm{pH} 4.5)$, containing $1.0 \mathrm{M} \mathrm{KCl}$ at a flow rate of $1 \mathrm{ml} \mathrm{min}^{-1}$ using a fast protein liquid chromatography system (Amersham Biosciences, Sweden). The fraction showing maximum absorbance at $280 \mathrm{~nm}$ and laccase activity was collected and concentrated using Amicon Ultracentrifugal filter tubes with $3 \mathrm{kDa}$ cut off membrane. The effluents were diluted appropriately with $0.1 \mathrm{M}$ sodium acetate buffer $(\mathrm{pH} 5.0)$ and were incubated with $50 \mathrm{U}$ of partially purified laccase at $30^{\circ} \mathrm{C}$ and $100 \mathrm{rpm}$. Change in the color was monitored periodically as described above.

\subsection{Estimation of lignin-degrading enzymes in the whole fungal culture}

The activity of the lignin degrading enzymes, lignin peroxidase (LiP), manganese peroxidase $(\mathrm{MnP})$ and laccase was measured in the culture supernatants of NIOCC \#2a grown in the absence and presence of sonicated and unsonicated effluents on day 0,3,6 and 9. Activity of LiP was determined by measuring the rate of oxidation of veratryl alcohol to veratraldehyde in the presence of $\mathrm{H}_{2} \mathrm{O}_{2}$ (Tien and Kirk, 1988). Activity of MnP was determined by measuring the rate of oxidation of veratryl alcohol to veratraldehyde in the presence of $\mathrm{Mn}$ and $\mathrm{H}_{2} \mathrm{O}_{2}$ (Paszczynski et al., 1988). Laccase was assayed by measuring oxidation of $1 \mathrm{mM}$ ABTS (2,2'-azino-bis-(3-ethylbenzothazoline-6-sulfonate) at $405 \mathrm{~nm}$ (Niku-Paavola et al., 1988). Units were calculated as $\mu \mathrm{M}$ of the substrate transformed minute ${ }^{-1}$ litre $^{-1}$ of

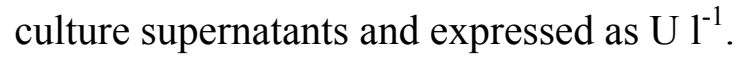

\subsection{Fungal biomass preparation for biosorption}

The culture supernatants containing effluents were further subjected to biosorption using the fungal biomass of NIOCC \#2a as follows. The culture was grown in LN medium. After six days, the growth medium was decanted and the biomass was rinsed several times with distilled water to remove the residual medium and inactivated in $\mathrm{NaCl}$ solution $\left(9 \mathrm{~g} \mathrm{l}^{-1}\right)$ by autoclaving at $121^{\circ} \mathrm{C}$ for $15 \mathrm{~min}$. The biosorption studies were carried out with; 1) wet biomass (equivalent to $0.5 \mathrm{~g}$ dry weight), after squeezing through cheese cloth to remove water, 2) $0.5 \mathrm{~g}$ lyophilized biomass and 3 ) $0.5 \mathrm{~g}$ of lyophilized powdered biomass $(100-200 \mu \mathrm{m})$. These were separately introduced in $100 \mathrm{ml}$ Erlenmeyer 
flask containing $20 \mathrm{ml}$ of whole culture-treated supernatant. Effluents without fungal biomass served as control. The flasks were incubated at $30^{\circ} \mathrm{C}$ and $100 \mathrm{rpm}$. Change in color, COD, total phenolics and toxicity were estimated at regular intervals after centrifugation at $5000 \mathrm{rpm}$ for $10 \mathrm{~min}$.

\subsection{Toxicity test}

Toxicity test of the effluents after each step of treatment was carried out. Treated and untreated effluents were serially diluted with $0.22 \mu \mathrm{m}$-filtered seawater. Bioassay was carried out in disposable multiwell test plate with $24(6 \times 4)$ test wells. The nauplii (10 organisms) were incubated in the suitably diluted effluents at room temperature in the dark and mortality was estimated after $24 \mathrm{~h}$. Lethal concentration that resulted in $50 \%$ mortality $\left(\mathrm{LC}_{50}\right.$ value) by $24 \mathrm{~h}$ was calculated with $95 \%$ confidence limits with the aid of computer program EPA Probit analysis, version 1.5, (Finney, 1971).

\subsection{Analytical methods}

Total phenolics were measured using Folin-Ciocalteau method and calculated in $\mathrm{g} \mathrm{L}^{-1}$ (Singleton and Rossi, 1965). Catechol (Sigma Chemicals, Mo, USA) was used as the reference standard. The reduction in total phenolics was expressed in percentage.

Chemical oxygen demand (COD) was estimated by open reflux method (APHA, AWWA, WEF, 2005). The values calculated in $\mathrm{mg} \mathrm{O}_{2} \mathrm{~L}^{-1}$ were expressed as percentage reduction.

Electrospray ionization mass spectrometry (ESI-MS) analysis was performed on a quadrapole-time of flight mass spectrometer (Model Qstar XL, Applied Biosystems, Rotkrenz-Switzerland). Effluents after each stage of treatment were freeze-dried. The lyophilized samples were dissolved in methanol:water (1:1) and directly analyzed by ESI-MS. The samples were introduced at a constant flow rate into the electrospray source using an integrated syringe pump. The mass/charge (m/z) MS-survey range was $0-1000$ in positive mode.

Proton nuclear magnetic resonance (NMR) spectra were recorded with Bruker Avance 300 spectrometer $(300 \mathrm{MHz})$ in deuterated water $\left(\mathrm{D}_{2} \mathrm{O}\right)$. Effluents after each stage of treatment were freezedried. The lyophilized samples were dissolved in $\mathrm{D}_{2} \mathrm{O}$ and the chemical shifts were recorded in ppm.

Fourier transform infra-red spectra (FTIR) of lyophilized fungal mycelium of NIOCC \#2a, before and after various steps of treatment, were recorded between 4000 and $700 \mathrm{~cm}^{-1}$ using FTIR (model 8201PC, Shimadzu, Japan) with $4 \mathrm{~cm}^{-1}$ resolution. Pellets were prepared by mixing $5 \mathrm{mg}$ of lyophilized 
mycelia with $50 \mathrm{mg} \mathrm{KBr}$ (dried at $105^{\circ} \mathrm{C}$ for $72 \mathrm{~h}$ ) using DRS (diffused reflectance spectroscopy) accessory.

\subsection{Statistical analyses}

The significance of the results obtained was evaluated by one-way analysis of variance (ANOVA) and Tukey post-hoc using the software Prism Pad 5 for Windows (version 5.03).

\section{Results and Discussion}

The four effluents differed significantly in their COD content, color units and turbidity (Table 1). As per the information furnished by the concerned industries, ROF and ROR were reverse osmosis feed and rejects respectively. CAT I and CAT O were anaerobically digested, while CAT O was further subjected to aerobic digestion.

\subsection{Effect of sonication on the effluents - Step 1}

Acoustic irradiation (sonication) removed the foul odor of the effluents significantly and reduced the turbidity by $10-40 \%$. However, there was no reduction in COD, color, total phenolics and toxicity. A reduction in the absorbance in UV region was observed but the pattern of the spectra remained unchanged. There was negligible change in the absorbance or spectral pattern in the visible region (Fig. $1)$.

Low-frequency ultrasound treatment (sonication) alone cannot mineralize the pollutants and the time-scale and energy requirement makes it cost prohibitive and unfeasible. However, wastewater treatment using sonication in combination with other conventional oxidation methods is recommended (Sangave et al., 2007; Sangave and Pandit, 2006). Pre-treatment of distillery waste water with sonication has been shown to increase the biodegradability during conventional aerobic oxidation (Sangave and Pandit, 2006) and reduce the toxicity of the original effluent (Gonze et al., 1999). In our study, sonication alone was not effective in reducing color, COD, total phenolics and toxicity .

\subsection{Bioremediation of the effluents with the whole fungal culture - Step 2}

Whole culture of the ligninolytic fungus NIOCC \#2a was chosen in the step 2 treatment for the following reasons; 1) Molasses waste waters contain reducing sugars which can easily be utilized by the live fungus for its growth and enzyme production, 2) Incubation period of nine days in the step 2 was to provide maximum allowance for enzymatic degradation of the effluents. Experiments were conducted by addition of unsonicated and sonicated effluents separately to the 6-day old culture of the marine- 
derived fungus NIOCC \#2a. No significant change in the $\mathrm{pH}$ was observed during the incubation period. Dry biomass of the fungus increased by 5-10\% in the presence of various effluents. Reduction in color, COD and phenolic content were significantly greater in the culture supplemented with sonicated effluents (see the P values in Table 2). The reduction in color in the culture supernatant supplemented with unsonicated effluents ranged from 20-30\% whereas it was 40-60\% in sonicated effluents. Similarly, COD reduction in unsonicated and sonicated effluents was in the range of 30-50\% and $50-70 \%$ respectively. Total phenolics were reduced in the range of $25-45 \%$ in unsonicated effluents whereas in sonicated effluents it ranged from 50-65\% (Table 2). Besides color, toxicity of molasses-based effluents is a major concern for environmental remediation. Toxicity as estimated by $\mathrm{LC}_{50}$ values against Artemia larvae was reduced 2-3 folds. In particular, sonicated ROF and CAT I showed greater reduction in toxicity than the unsonicated ones (Table 3).

Production of $\mathrm{MnP}$ and laccase were initially inhibited in the effluent-supplemented cultures but laccase steadily increased to overcome this inhibition by day 3-6 (Fig. 2). There was a positive correlation between decolorization and laccase production (Fig. 2) in the presence of all the effluents (the $\mathrm{P}$ value being 0.001$)$ whereas it was negatively correlated with $\mathrm{MnP}$ production $(\mathrm{P}=(-) 0.001)$. Production of LiP was negligible in this fungus and was totally inhibited in the presence of the effluents. However, these results do not confirm the involvement of laccase in in situ decolorization, as stress conditions such as pollutants are known to induce laccase production. Therefore, an in vitro study was conducted using partially purified laccase for decolorization of these effluents. An overall 16-18\% decolorization was achieved in $12 \mathrm{~h}$ (data not shown). Involvement of several other factors besides laccase in in vivo decolorization cannot be ruled out.

González et al. (2008) reported a direct correlation between decolorization of melanoidin fractions and molasses waste water with that of laccase production in Trametes sp I-62. In an earlier study using another marine-derived fungus NIOCC \#312, decolorization of molasses spent wash was reported to be directly correlated with glucose oxidase production (Raghukumar et al., 2004). Intracellular sugar oxidase enzymes were considered to play a major role in decolorization of molasses spent wash in Coriolus sp. No. 20 (Mohana et al., 2009). Thus, it appears that the enzyme system responsible for decolorization of specific effluent varies from fungus to fungus.

Although laccase production was repressed immediately after addition of the effluents (day 0) the fungus overcame this inhibitory effect and its production increased by several folds by day 3 itself 
(Fig. 2). These nutrient-containing effluents might prolong the primary phase of the fungal growth which would ultimately delay laccase production. On the contrary, induction of laccase by molasses spent wash and melanoidin fractions in several white-rot fungi has been reported (D'Souza-Ticlo et al., 2006; González et al., 2008). As hypothesized by González et al. (2008) copper is released during breakdown of melanoidins which can induce laccase production. D'Souza et al. (2006) have shown induction of laccase by several thousand folds in NIOCC \#2a by copper. Aromatic monomers, which are some of the breakdown products of molasses, were also shown to induce laccase production in NIOCC \#2a (D’Souza et al., 2006) and in Trametes sp. 1-62 (Terrón et al., 2004). In the presence of synthetic melanoidin pigments, activity of the partially purified laccase of NIOCC \#2a increased (data not shown). Thus besides increased production, induction in laccase activity per se was observed in this fungus in the presence of the molasses-based effluents. The above results confirm that laccases are induced in fungi under stress conditions. Further, sonication also might exert a positive influence on the oxygendependent laccase activity as it helps in degassing and removal of $\mathrm{H}_{2} \mathrm{~S}$ from the effluents. Fungal enzymes that are not inhibited in the presence of industrial effluents may make them good candidates for bioremediation.

In the present study it was noticed that after addition of the effluents, the fungal mycelia turned dark brown in color. In the whole fungal culture treatment, biosorption by the live mycelia would also be playing a role in removal of color from the culture broth to a certain extent. The FTIR spectra of the fungal biomass before and after treatment were recorded and the band positions of the main functional groups are listed in Table 4. Fourier transform infra-red analysis of all the biological sorbent materials show intense absorption bands around $3500-3000 \mathrm{~cm}^{-1}$, representing stretching vibrations of hydroxyl and/or amino groups (Bayramoğlu and Arica, 2007). Unloaded fungal biomass (NIOCC \#2a) had intense peaks at a frequency level of 3500-3200 and $1533.3 \mathrm{~cm}^{-1}$ representing amino groups stretching vibrations. Mycelia in the Step 2 treatment at $0 \mathrm{~h}$ (immediately after addition of the effluent) showed no change in this peak (Table 4). Lowering of band to $3271 \mathrm{~cm}^{-1}$ at $24 \mathrm{~h}$ suggested slow adsorption of the effluent. The shift in the peak to $3290.3 \mathrm{~cm}^{-1}$ by day 9 may be attributed to desorption/degradation of the adsorbed effluent. The extracellular ligninolytic enzymes would be simultaneously biodegrading and mineralizing the colored compounds (Park et al., 2007). The changes observed in the spectra of unloaded biomass and different stages of loaded biomass may indicate that several other functional groups are also responsible for biosorption of the effluent components (Table 4). 


\subsection{Further bioremediation by biosorption - Step 3}

The culture supernatants containing effluents from step 2 were subjected to biosorption for removal of the residual color using a fresh batch of biomass of the same fungus. We compared biosorption using heat-inactivated 1) wet biomass, 2) lyophilized biomass and 3) lyophilized powdered biomass. The first method yielded maximum removal of both color and COD whereas, the other two methods resulted in increase in COD without decreasing the color. This may have happened due to release of cellular contents during the drying process of the mycelia. Tigini et al. (2010) also observed an increase in COD in several of textile effluents using similar methods.

Adsorption by the wet biomass reached its equilibrium by $2 \mathrm{~h}$. The reduction in color in unsonicated effluents after biosorption increased up to 50-55 \% whereas in sonicated effluents the increase was even greater, being up to $60-80 \%$ (Table 2). The percentage COD and total phenolics reduction also increased significantly. Toxicity of the unsonicated as well as sonicated effluents after biosorption was not significantly reduced from Step 2 except in CAT O (Table 3). Over all reduction in toxicity was comparatively higher in the sonicated effluents than in the unsonicated effluents except in CAT O.

The FTIR spectrum of the effluent- loaded biomass during Step 3 treatment showed lowering of the band corresponding to the amino group up to $3247.9 \mathrm{~cm}^{-1}$ due to $-\mathrm{CH}$ stretching vibrations (Table 4). The carboxyl chelate stretching vibrations of amide I band was observed at 1681.8 and $1691.5 \mathrm{~cm}^{-1}$ for unloaded and effluent-loaded biomass respectively. An absorption band at $1533.3 \mathrm{~cm}^{-1}$ of the unloaded biomass can be attributed to amide II band. This band slightly shifted to $1537.2 \mathrm{~cm}^{-1}$ in the effluent loaded biomass. No shifting in the absorption band at $1240.1 \mathrm{~cm}^{-1}$ was noticed. An intensity decrease and a slight band shifting from 1076.2 to $1078.1 \mathrm{~cm}^{-1}$ relates to $\mathrm{P}=\mathrm{O}$ stretching and $\mathrm{P}-\mathrm{OH}$ stretching vibrations. New absorption bands appearing between $700-900 \mathrm{~cm}^{-1}$ for the effluent-loaded biomass may be attributed to the aromatic - $\mathrm{CH}$ - bending vibrations. An over all shift and change in the intensity of several functional groups indicate their relevance in biosorption.

The use of dead biomass for biosorption has several advantages, as they do not require nutrients for growth, will not be inhibited by the toxic effluents and there is no fear of their pathogenicity or toxins (Prigione et al., 2008). Heat-inactivation of biomass increases hydrophilicity of the surface (Bayramoğlu and Arica, 2007). Autoclaved fungal biomass (2 $\mathrm{g}$ wet weight) of Aspergillus oryzae strain Y-2-32, removed $65 \%$ of melanoidin pigments within 4 days by adsorption (Ohmomo et al., 1988). 
Biosorption potential of microbial exopolymeric substances (EPS) is well known (Gadd, 2009). Basidiomycetous fungi are reported to produce large amounts of EPS (Smith et al., 2002). These polymeric substances form a sheath around fungal hyphae. They are highly hydrophilic and become gellike by absorbing water (Bes et al., 1987). Additionally, microbial biomass acts as an ion exchanger by virtue of reactive groups available on the cell surfaces (Gadd, 2009). Mucoraceous fungi rich in chitosan are a good source of biosorption of dyes (Prigione et al., 2008), similarly the white-rot fungi with their high EPS content might offer a novel source of biosorption of industrial effluents. The basidiomycetous fungus NIOCC \#2a produced $2.3 \mathrm{~g}$ of EPS $\mathrm{L}^{-1}$ of the LN medium. It showed CNS (Carbon:Nitrogen:Sulphur) ratio of 4.5:0.76:10, and therefore appeared to be sulfated polysaccharide (D’Souza et al., 2006). The EPS forms aggregates around fungal mycelium and stains with alcian blue (Raghukumar et al., 2006). The heat-inactivated mycelia of NIOCC \#2a also stained with alcian blue indicating that EPS was not affected by autoclaving. Thus, it might play a role in biosorption of melanoidin pigments in the present study. Bayramoğlu and Arica, (2007) reported biosorption of textile dyes by the white-rot fungus Tremetes versicolor, although the role of EPS was not mentioned.

\subsection{Mass Spectrometry and NMR analysis}

In order to support the above data, spectrometric analyses was carried out. For this purpose CAT O was selected as a representative effluent. Comparative mass finger print values recorded (ESI-MS) of untreated CAT $\mathrm{O}$ and after each step of treatment showed extensive variations. Peak with higher molecular mass present in the untreated effluent disappeared after sonication and several peaks clustered in the range of 250-350 m/z. After Step 2, five distinct clusters of peaks appeared in the range of $50-500 \mathrm{~m} / \mathrm{z}$ confirming degradation. Also several new peaks were observed in higher molecular mass range $(600-850 \mathrm{~m} / \mathrm{z})$ indicating simultaneous dimerization / polymerization of the components in the effluent. We hypothesize that sonication hydromechanically shears the melanoidin pigment particles and makes them available for enzymatic degradation. This was evident by ESI-MS where the number of peaks in the lower $(100-400 \mathrm{~m} / \mathrm{z})$ region increased. Maximum number of peaks disappeared after the Step 3 indicating biosorption of the degraded components.

The NMR spectra after each stage of treatment showed reduction in the intensity of chemical shifts in the region of 7-9 ppm. This region attributes to the aromatic nature of the effluent. After sonication, a change in aliphatic components occurred as was evident by appearance of additional chemical shifts in the range of 0-3.7 ppm. Besides, the chemical shift $\delta 8.4$ disappeared completely. 
After step 2, the number of peaks in the range of 0-3.7 ppm increased. Of these peaks, $\delta 0.7$ and 1.2 were contributed by the fungal metabolites as confirmed by $\mathrm{H}^{1} \mathrm{NMR}$ of the culture supernatant of NIOCC \# 2a (data not shown). The intensity of these peaks decreased and chemical shifts at $\delta 7.8,7.4$ and 7.2 disappeared completely after step 3. Aromatic compounds are some of the major contributors of toxicity (Raghukumar et al., 2004). According to NMR data, we observed a substantial decrease in aromatic character of the treated effluent. Sonication reduced the absorbance of the effluents in the UV region which may be attributed to a reduction in aromatic compounds as suggested by Beltran et al. (2000). This was further confirmed by disappearance of chemical shifts in the $\mathrm{H}^{1} \mathrm{NMR}$ spectra.

Molasses-based effluents containing high COD and color are some of the most difficult effluents to treat. Each method has its own advantages and disadvantages and therefore a combination of different techniques would help in resolving this problem. Low frequency sonication for a short duration is an eco-friendly and cost-effective approach. Sonication combined with cellulase treatment (Sangave and Pandit, 2006), sonication/ozone treatment followed by mixed microbial consortium to treat distillery waste water has been tried with some success (Sangave et al., 2007). Decolorization and detoxification of molasses spent wash with lignin-degrading fungi has been reported (Miyata et al., 2000; D'SouzaTiclo et al., 2006; Raghukumar et al., 2006; Thakker et al., 2006). Although removal of metals and decolorization of dye-containing effluents through biosorption has been extremely successful (Gadd, 2009; Prigione et al., 2008; Verma et al., 2010), its use in treatment of molasses-based effluents has not been reported widely. Such a hybrid technology combining sonication followed by whole-culture treatment for decolorization and detoxification and subsequent biosorption of the residual color eliminates use of chemicals as is generally practiced in advanced oxidation processes. The successful application of the same three step-process for treatment of four different effluents strengthens our findings. Besides, it will offer a huge saving in precious fresh water used for diluting the effluent before its release for meeting the zero discharge regulation of pollution control boards.

\section{Conclusion}

Sonication of the molasses-based effluents in the first step removed the foul odor and turbidity. It increased their accessibility to enzymatic biodegradation by the ligninolytic fungus in the next step. This was evident from enhanced reduction in color, COD, total phenolics and toxicity. Biosorption using heat-killed wet biomass of the same fungus decolorized the effluent further. Thus, a three step 
combinatorial technology for decolorization and detoxification of recalcitrant molasses-based pollutants is recommended.

\section{Acknowledgements}

The first author thanks Council for Scientific and Industrial Research (CSIR), New Delhi for a senior research fellowship. The corresponding author acknowledges the research scheme No. 21(0649)/06/EMR-II of CSIR.

\section{References:}

Agarwal, R., Lata, S., Gupta, M., Singh, P. 2010. Removal of melanoidin present in distillery effluent as a major colorant: a review. J. Environ. Biol. 31(4), 521-528.

Aksu, Z. 2005. Application of biosorption for the removal of organic pollutants; a review. Process Biochem. 40 (3-4), 997-1026.

APHA, AWWA, WEF, 2005. Standard Methods for the Examination of Water and Wastewater, 21 ed. American Public Health Association (APHA), American Water Work Association (AWWA), Water Environmental Federation (WEF), Washington DC.

Bayramoğlu, G., Arica, M.Y., 2007. Biosorption of benzidine based textile dyes "Direct Blue 1 and Direct Red 128" using native and heat-treated biomass of Trametes versicolor. J. Hazard. Mater. $143(1-2), 135-143$.

Beltran, F.J., Garcia-Araya, J.F., Alvarez, P.M., 2000. Continuous flow integrated chemical (ozone)activated sludge system treating combined agro-industrial domestic wastewater. Environ. Prog. 19 (1), 28-35.

Bes, B., Petterson, B., Lenholm, H., Iverson, T., Eriksson, K.E., 1987. Synthesis, structure and enzyme degradation of an extracellular glucan produced in nitrogen-starved culture of the white-rot fungus Phanerochaete chrysosporium. Biotechnol. Appl. Biochem. 9 (4), 310-318.

D’Souza, D.T., Tiwari, R., Sah, A.K., Raghukumar, C., 2006. Enhanced production of laccase by a marine fungus during treatment of colored effluents and synthetic dyes. Enzyme Microb. Technol. 38 (3-4), 504-511.

D’Souza-Ticlo, D.T., Verma, A.K., Mathew, M., Raghukumar, C., 2006. Effect of nutrient nitrogen on laccase production, its isozyme pattern and effluent decolorization by the fungus NIOCC \#2a, isolated from mangrove wood. Indian J. Mar. Sci. 35 (4), 364-372. 
Finney, D.J., 1971. Probit Analysis, $3^{\text {rd }}$ ed., Cambridge University Press, Cambridge.

Gadd, G.M., 2009. Biosorption: Critical review of scientific rationale, environmental importance and significance for pollution treatment. J. Chem. Technol. Biotechnol. 84 (1), 13-28.

Gold, M.H., Alic, M., 1993. Molecular biology of the lignin-degrading basidiomycete Phanerochaete chrysosporium. Microbiol. Reviews 57 (3), 605-622.

González, T., Terrón, M. C., Yagüe, S., Junca, H., Carbajo, J. M., Zapico, E. J., Silva, R., AranaCuenca, A., Téllez, A., González, A. E., 2008. Melanoidin-containing wastewaters induce selective laccase gene expression in the white-rot fungus Trametes sp. I-62. Res. Microbiol. 159 (2), 103-109.

Gonze, E., Fourel, L, Gonthier, Y., Boldo, P., Bernis, A., 1999. Wastewater pretreatment with ultrasonic irradiation to reduce toxicity. Chem. Eng. J. 73 (8), 93-100.

Kennedy, K.J., Pham, T.T., 1995. Effect of anaerobic sludge source and condition on biosorption of PCP. Water Res. 29 (10), 2360-23066.

Kohlmeyer, J., Kohlmeyer, E., 1979. Marine Mycology: The higher fungi. Academic Press, New York

Miyata, N., Mori, T., Iwahori, K., Fujita, M., 2000. Microbial decolorisation of melanoidin-containing wastewaters: Combined use of activated sludge and the fungus Coriolus hirsutus. J. Biosci. Bioeng. 89 (2), 145-150.

Niku-Paavola, M.L., Karhuner, E., Salola, P., Raunio, V., 1988. Lignolytic enzymes of the white-rot fungus Phlebia radiata. Biochem. J. 254 (), 877-884.

Mohana, S., Acharya, B.K., Madamwar, D., 2009. Distillery spent wash: Treatment and potential applications. J. Hazard. Mater. 163 (1), 12-15.

Ohmomo, S., Kainuma, M., Kamimura, K., Sirianuntapiboon, S., Aoshima I., Atthasampunna, P., 1988. Adsorption of melanoidin to the mycelia of Aspergillus oryzae Y-2-321, Agric. Biol. Chem. 52 (2), 381-386.

Park, C., Lee, M., Lee, B., Kim, S-W., Chase, H.A., Lee, J., Kim, S., 2007. Biodegradation and biosorption of synthetic dyes by Funalia trogii. Biochem. Eng. J. 36 (1), 59-65.

Paszczynski, A., Crawford, R.L., Huynh, V.B., 1988. Manganese peroxidase of Phanerochaete chrysosporium: purification. Meth. Enzymol. 61, 264-270.

Prigione, V., Varese, G.C., Casieri, L.,Marchisio, V.F., 2008. Biosorption of simulated dyes effluents by inactivated fungal biomasses. Bioresour. Technol. 99 (9), 3559-3567. 
Raghukumar, C., Mohandass, C., Kamat, S., Shailaja, M.S., 2004. Simultaneous detoxification and decolorization of molasses spent wash by the immobilized white-rot fungus Flavodon flavus isolated from a marine habitat. Enzyme Microb. Technol. 35 (2-3), 197-202.

Raghukumar, C., Shailaja, M.S., Parameswaran, P.S., Singh, S.K., 2006. Removal of polycyclic aromatic hydrocarbons from aqueous media by the marine fungus NIOCC \# 312: involvement of lignin-degrading enzymes and exopolysaccharides. Indian J. Mar. Sci. 35 (4), 373-379.

Sangave, P. C., Pandit, A. B., 2006. Ultrasound and enzyme assisted biodegradation of distillery wastewater. J. Environ. Manag. 80 (1), 36-46.

Sangave, P. C., Gogate, P.R., Pandit, A. B., 2007. Ultrasound and ozone assisted biological degradation of thermally pretreated and anaerobically pretreated distillery wastewater. Chemosphere 68 (1), $42-50$.

Satyawali, Y., Balakrishnan, M., 2008. Wastewater treatment in molasses-based alcohol distilleries for COD and color removal: A review. J. Environ. Manag. 86 (3), 481-497

Singleton, V.L., Rossi, J.A. Jr., 1965. Colorimetry of total phenolics with phosphomolybdicphosphotungstic acid reagents. Am. J. Enol. Vitic 16 (3), 144-158.

Smith, J.E., Rowan, N.J., Sullivan, R., 2002. Medicinal mushrooms: a rapidly developing area of biotechnology for cancer therapy and other bioactivities. Biotechnol. Lett. 24 (22), 1839-1845.

Terrón, M.C., González, T., Carbajo, J.M., Yagüe, S., Arana-Cuenca, A., Téllez, A., 2004. Structural close-related aromatic compounds have different effects on laccase activity and on lcc gene expression in the ligninolytic fungus Trametes sp. I-62, Fungal Genet. Biol. 41 (10), 954-962.

Thakker, A.P., Dhamankar, V.S., Kapadnis, B.P., 2006. Biocatalytic decolorisation of molasses by Phanerochaete chrysosporium. Bioresour. Technol. 97 (12), 1377-1381.

Tigini, V., Prigione, V., Giansanti, P., Mangiavillano, A., Pannocchia, A., Varese, G.C., 2010. Fungal biosorption, an innovative treatment for the decolourisation and detoxification of textile effluents. Water 2 (3), 550-565.

Tien, M., Kirk, T.K., 1988. Lignin peroxidase of Phanerochaete chrysosporium. Meth. Enzymol. 161, 238-249.

Verma, A.K., Raghukumar, C., Verma, P., Shouche, Y.S., Naik, C.G., 2010. Four marine-derived fungi for bioremediation of raw textile mill effluents. Biodegr. 21(2), 217-233. 


\section{Legends to the Figures}

Fig. 1. Visible and UV spectra of the four effluents; untreated ( - ), after sonication ( - ), after treatment with the whole fungus (_ - - ) and after biosorption with wet, heat-killed biomass (- - - -). The UV and visible spectra were taken at different dilutions. The insets indicate the initial and final colors of the effluents.

Fig. 2. Decolorization, laccase and MnP production by NIOCC \#2a in LN medium during whole-fungal culture treatment (Step 2). Four graphs on the left are with unsonicated effluents ( - ), and the four graphs on the right are with sonicated effluents (_ ) Laccase and MnP production in the control culture, without any effluents are shown as dotted lines (................) in all the graphs.

\section{Supplementary Figures}

Fig. 1. FTIR spectra of A) unloaded fungal biomass and loaded with CAT O, B) Step 2, day 0; C) Step 2, day 1; D) Step 2, day 9; E) Step 3 (biosorption), 2 h.

Fig. 2. Mass spectra finger printing of A) untreated CAT O, B) after Step 1-sonication, C) after Step 2whole fungus treatment, D) after Step 3- biosorption.

Fig. 3. $\mathrm{H}^{1}$ NMR spectra A) untreated CAT O; B) after Step 1-sonication; C) after Step 2- whole fungus treatment; D) after Step 3- biosorption. 
Table 1.

Physico-chemical characteristics of the molasses-based effluents.

\begin{tabular}{|c|c|c|c|c|}
\hline \multirow{3}{*}{$\begin{array}{l}\text { Source of the effluents } \\
\text { Parameters analysed }\end{array}$} & \multicolumn{4}{|c|}{ Effluents Analysed } \\
\hline & \multicolumn{2}{|c|}{ Sugar Mill } & \multicolumn{2}{|c|}{ Biotech Pharmaceutical Company } \\
\hline & $\begin{array}{c}\text { ROF } \\
\text { (Reverse } \\
\text { Osmosis } \\
\text { Feed) }\end{array}$ & $\begin{array}{c}\text { ROR } \\
\text { (Reverse } \\
\text { Osmosis } \\
\text { Reject) }\end{array}$ & $\begin{array}{l}\text { CAT I } \\
\text { (Conventional } \\
\text { aeration tank } \\
\text { Inlet) }\end{array}$ & $\begin{array}{c}\text { CAT O } \\
\text { (Conventional } \\
\text { aeration tank } \\
\text { Outlet) }\end{array}$ \\
\hline $\mathrm{pH}$ & 7.5 & 7.4 & 7.7 & 7.6 \\
\hline $\operatorname{COD}\left(g^{-1}\right)$ & 30.8 & 52.8 & 23.2 & 18.0 \\
\hline Total Phenolics $\left(\mathrm{g} \mathrm{L}^{-1}\right)$ & 1.9 & 2.0 & 1.9 & 1.7 \\
\hline Color Units (Pt-Co Units) & 72,500 & 49,000 & 52,000 & 35,000 \\
\hline Total Reducing Sugars $\left(\mathrm{g} \mathrm{L}^{-1}\right)$ & 3.8 & 1.7 & 1.7 & 1.2 \\
\hline Total Solids $\left(\mathrm{g} \mathrm{L}^{-1}\right)$ & 0.04 & 0.061 & 0.025 & 0.028 \\
\hline Sulphates $\left(\mathrm{SO}_{4}^{--}\right)\left(\mathrm{g} \mathrm{L}^{-1}\right)$ & 0.12 & 0.21 & 0.82 & 0.78 \\
\hline Turbidity (NTU) & 96.0 & 98.9 & 338 & 185 \\
\hline
\end{tabular}


Table 2.

A comparison of the decolorization, reduction in COD and phenolics.

\begin{tabular}{|c|c|c|c|c|c|c|c|}
\hline \multirow[t]{2}{*}{ Effluent } & \multirow[t]{2}{*}{ Treatment } & \multicolumn{2}{|c|}{ \% Decolorization } & \multicolumn{2}{|c|}{ \% Reduction in COD } & \multicolumn{2}{|c|}{ \% Reduction in Phenolics } \\
\hline & & $\begin{array}{l}\text { After whole- } \\
\text { culture } \\
\text { treatment } \\
\text { (Step 2) }\end{array}$ & $\begin{array}{l}\text { Followed } \\
\text { by } \\
\text { biosorption } \\
\text { (Step 3) }\end{array}$ & $\begin{array}{c}\text { After } \\
\text { whole- } \\
\text { culture } \\
\text { treatment } \\
\text { (Step 2) }\end{array}$ & $\begin{array}{l}\text { Followed } \\
\text { by } \\
\text { biosorption } \\
\text { (Step 3) }\end{array}$ & $\begin{array}{c}\text { After } \\
\text { whole- } \\
\text { culture } \\
\text { treatment } \\
\text { (Step 2) }\end{array}$ & $\begin{array}{l}\text { Followed } \\
\text { by } \\
\text { biosorption } \\
\text { (Step 3) }\end{array}$ \\
\hline \multirow{2}{*}{ ROF } & Without sonication & $\begin{array}{c}20 \\
\pm 3.9\end{array}$ & $\begin{array}{c}49 \\
\pm 2.3\end{array}$ & $\begin{array}{c}38 \\
\pm 6.5\end{array}$ & $\begin{array}{c}41 \\
\pm 7.1\end{array}$ & $\begin{array}{c}30 \\
\pm 3.2\end{array}$ & $\begin{array}{c}48 \\
\pm 7.4\end{array}$ \\
\hline & With sonication & $\begin{array}{c}41 \\
\pm 1.7\end{array}$ & $\begin{array}{c}63 \\
\pm 3.3\end{array}$ & $\begin{array}{c}56 \\
\pm 4.4\end{array}$ & $\begin{array}{c}62 \\
\pm 4.1\end{array}$ & $\begin{array}{c}65 \\
\pm 8.9\end{array}$ & $\begin{array}{c}74 \\
\pm 5.2\end{array}$ \\
\hline \multirow{2}{*}{ ROR } & Without sonication & $\begin{array}{c}27 \\
\pm 2.4\end{array}$ & $\begin{array}{c}50 \\
\pm 3.8\end{array}$ & $\begin{array}{c}38 \\
\pm 4.6\end{array}$ & $\begin{array}{c}48 \\
\pm 5.9\end{array}$ & $\begin{array}{c}26 \\
\pm 10\end{array}$ & $\begin{array}{c}36 \\
\pm 6.3\end{array}$ \\
\hline & With sonication & $\begin{array}{c}40 \\
\pm 3.3\end{array}$ & $\begin{array}{c}61 \\
\pm 2.4\end{array}$ & $\begin{array}{c}50 \\
\pm 2.8\end{array}$ & $\begin{array}{c}63 \\
\pm 3.5\end{array}$ & $\begin{array}{c}61 \\
\pm 14.2\end{array}$ & $\begin{array}{c}67 \\
\pm 6.2\end{array}$ \\
\hline \multirow{2}{*}{ CAT I } & Without sonication & $\begin{array}{c}27 \\
\pm 2.7\end{array}$ & $\begin{array}{c}50 \\
+3.3\end{array}$ & $\begin{array}{c}53 \\
\pm 2.5\end{array}$ & $\begin{array}{c}59 \\
\pm 4.8\end{array}$ & $\begin{aligned} & 37 \\
\pm & 10.7\end{aligned}$ & $\begin{array}{c}44 \\
\pm 8.1\end{array}$ \\
\hline & With sonication & $\begin{array}{c}56 \\
\pm 2.7\end{array}$ & $\begin{array}{c}75 \\
\pm 2.5\end{array}$ & $\begin{array}{c}71 \\
\pm 1.3\end{array}$ & $\begin{array}{c}74 \\
\pm 1.6\end{array}$ & $\begin{array}{c}49 \\
\pm 8.2\end{array}$ & $\begin{array}{c}58 \\
\pm 5.1\end{array}$ \\
\hline \multirow{2}{*}{ CAT O } & Without sonication & $\begin{array}{c}32 \\
\pm 4.1\end{array}$ & $\begin{array}{c}53 \\
\pm 4.6\end{array}$ & $\begin{array}{c}29 \\
\pm 6.3\end{array}$ & $\begin{array}{c}46 \\
\pm 6.7\end{array}$ & $\begin{array}{c}46 \\
\pm 1.4\end{array}$ & $\begin{array}{c}53 \\
\pm 2.8\end{array}$ \\
\hline & With sonication & $\begin{array}{c}60 \\
\pm 8.4\end{array}$ & $\begin{array}{c}78 \\
\pm 2.6\end{array}$ & $\begin{array}{c}49 \\
\pm 0.9\end{array}$ & $\begin{array}{c}53 \\
\pm 1.4\end{array}$ & $\begin{array}{c}52 \\
\pm 4.0\end{array}$ & $\begin{array}{c}61 \\
\pm 2.4\end{array}$ \\
\hline
\end{tabular}

P values obtained by one way-Analysis of variance (ANOVA): I) between unsonicated and sonicated effluents in Step 2 for color, COD and phenolics were 0.008, 0.002 and 0.06 respectively, II) for color, COD and phenolics between unsonicated and sonicated effluents in Step 3 were $0.01,0.01$ and 0.03 respectively and III) between Step 2 and Step 3 for reduction in color, COD and phenolics were 3.17E-07, 0.004 and 0.0002 respectively. 
Table 3.

A comparison of toxicity test ( $\mathrm{LC}_{50}$ values) of the unsonicated and sonicated effluents, after the whole fungal treatment (Step 2) followed by biosorption (Step 3).

\begin{tabular}{|c|c|c|c|c|c|c|}
\hline \multirow[t]{2}{*}{ Effluents } & \multicolumn{6}{|c|}{ Treatments } \\
\hline & $\begin{array}{l}\text { Without any } \\
\text { treatment } \\
\text { (control) }\end{array}$ & $\begin{array}{l}\text { whole-fungus } \\
\text { treatment of } \\
\text { unsonicated } \\
\text { effluent }\end{array}$ & $\begin{array}{l}\text { whole-fungus } \\
\text { treatment of } \\
\text { unsonicated } \\
\text { effluent } \\
\text { followed by } \\
\text { biosorption }\end{array}$ & $\begin{array}{l}\text { Effluent after } \\
\text { sonication } \\
\text { (Step 1) }\end{array}$ & $\begin{array}{l}\text { whole-fungus } \\
\text { treatment of } \\
\text { sonicated effluent } \\
\text { (Step 2) }\end{array}$ & $\begin{array}{l}\text { whole-fungus } \\
\text { treatment of } \\
\text { sonicated effluent } \\
\text { followed by } \\
\text { biosorption } \\
\text { (Step 3) }\end{array}$ \\
\hline $\mathrm{ROF}$ & $86(48-130)^{\mathrm{a}}$ & $234(178-331)^{b}$ & $290(202-366)^{b c}$ & $112(72-184)^{a}$ & $338(270-447)^{\mathrm{cd}}$ & $387(279-547)^{d}$ \\
\hline ROR & $114(66-172)^{\mathrm{a}}$ & $237(160-325)^{b}$ & $244(170-327)^{b}$ & $115(68-171)^{\mathrm{a}}$ & $294(201-433)^{b d}$ & $328(223-479)^{\mathrm{d}}$ \\
\hline CAT I & $165(110-229)^{\mathrm{a}}$ & $269(194-354)^{b}$ & $285(204-378)^{b}$ & $164(94-267)^{\mathrm{a}}$ & $345(240-496)^{\mathrm{C}}$ & $398(287-572)^{c}$ \\
\hline CAT O & $96(59-139)^{\mathrm{a}}$ & $214(138-332)^{b}$ & $335(207-452)^{\mathrm{c}}$ & $88(53-129)^{a}$ & $251(176-303)^{b}$ & $362(250-504)^{\mathrm{c}}$ \\
\hline
\end{tabular}


Table 4. Band positions at different steps of the treatment by FTIR technique.

\begin{tabular}{|c|c|c|c|c|c|}
\hline \multirow[b]{3}{*}{ Assignment } & \multicolumn{5}{|c|}{ Band Positions $\left(\mathrm{cm}^{-1}\right)$} \\
\hline & \multirow[t]{2}{*}{ Unloaded biomass } & \multicolumn{3}{|c|}{ Step 2} & \multirow{2}{*}{$\begin{array}{c}\text { Step } 3 \\
\text { After } 2 \mathrm{~h}\end{array}$} \\
\hline & & At $0 \mathrm{~h}$ & Day 1 & Day 9 & \\
\hline $\begin{array}{l}\text {-OH and/or }-\mathrm{NH} \\
\text { stretching } \\
\left(3500-3000 \mathrm{~cm}^{-1}\right)\end{array}$ & 3292.3 & 3292.3 & 3271.0 & 3290.3 & 3274.9 \\
\hline $\begin{array}{l}\text {-CH stretching } \\
\left(3000-2800 \mathrm{~cm}^{-1}\right)\end{array}$ & 2922.0 & 2927.7 & 2927.7 & 2939.3 & 2929.7 \\
\hline $\begin{array}{l}\text { Amid-I/ Amide-II } \\
\text { band } \\
\left(1800-1500 \mathrm{~cm}^{-1}\right)\end{array}$ & $\begin{array}{l}1681.8 \\
1637.5 \\
1533.3\end{array}$ & $\begin{array}{l}1651.0 \\
1635.5 \\
1537.2\end{array}$ & $\begin{array}{l}1693.4 \\
1635.5 \\
1537.2\end{array}$ & $\begin{array}{l}1649.0 \\
1637.5 \\
1529.4\end{array}$ & $\begin{array}{l}1691.5 \\
1635.5 \\
1537.2\end{array}$ \\
\hline $\begin{array}{l}\text { Mixed region } \\
\left(1500-1200 \mathrm{~cm}^{-1}\right)\end{array}$ & $\begin{array}{l}1463.9 \\
1240.1\end{array}$ & $\begin{array}{l}1469.7 \\
1247.9\end{array}$ & $\begin{array}{l}1467.7 \\
1236.3\end{array}$ & $\begin{array}{l}1460.0 \\
1236.3\end{array}$ & $\begin{array}{l}1465.0 \\
1240.1\end{array}$ \\
\hline $\begin{array}{c}\text { Polysaccharide } \\
\text { region }(1200-900 \\
\left.\mathrm{cm}^{-1}\right)\end{array}$ & 1076.2 & 1062.7 & 1072.0 & 1074.3 & 1078.1 \\
\hline $\begin{array}{l}\text { Finger print region } \\
\left(900-700 \mathrm{~cm}^{-1}\right)\end{array}$ & - & 777.3 & 774.3 & 757.0 & 754.1 \\
\hline
\end{tabular}

Unloaded biomass is the fungal mycelium without any effluent and the remaining steps were after the addition of CAT O. 


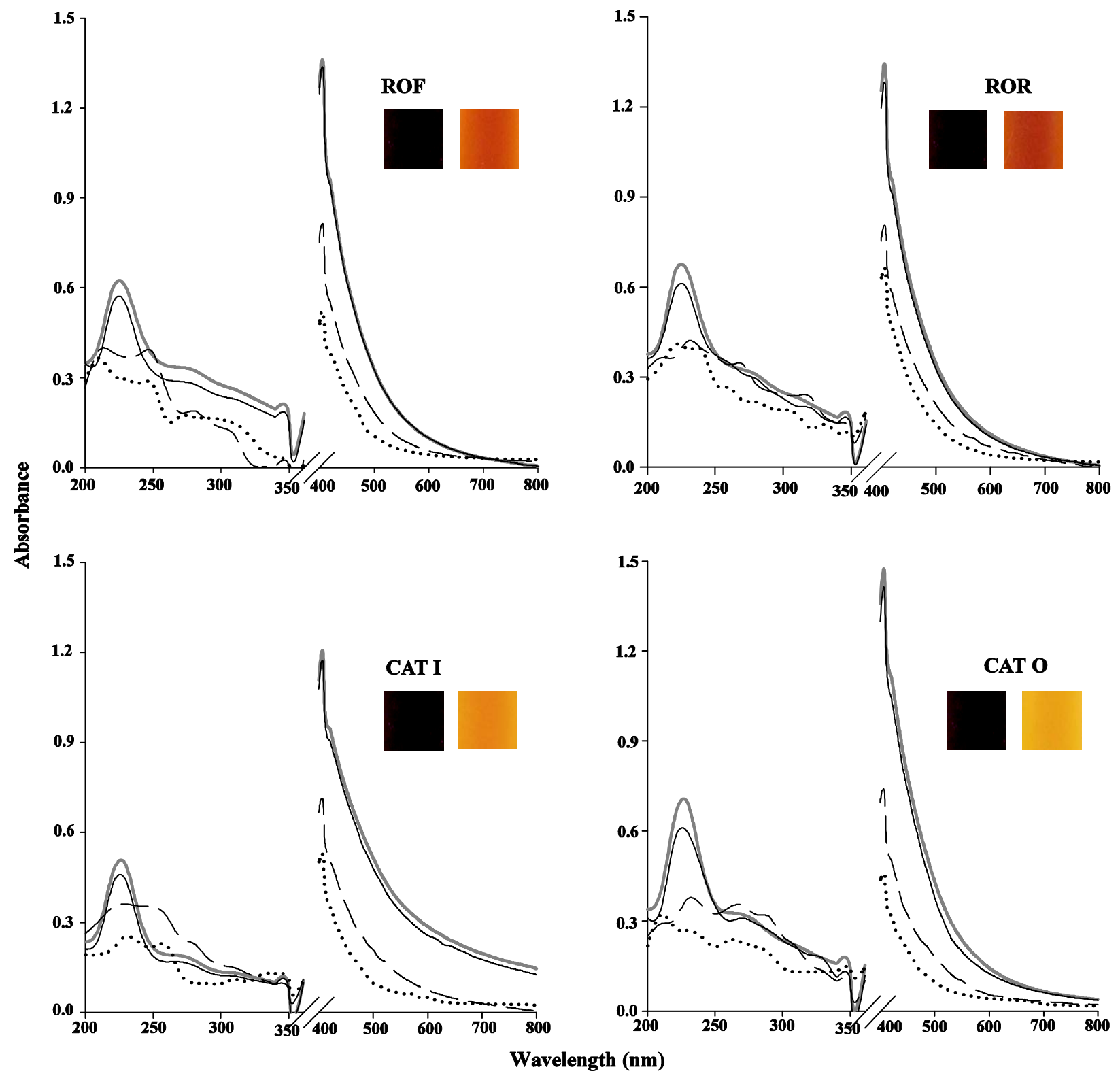

Fig. 1 

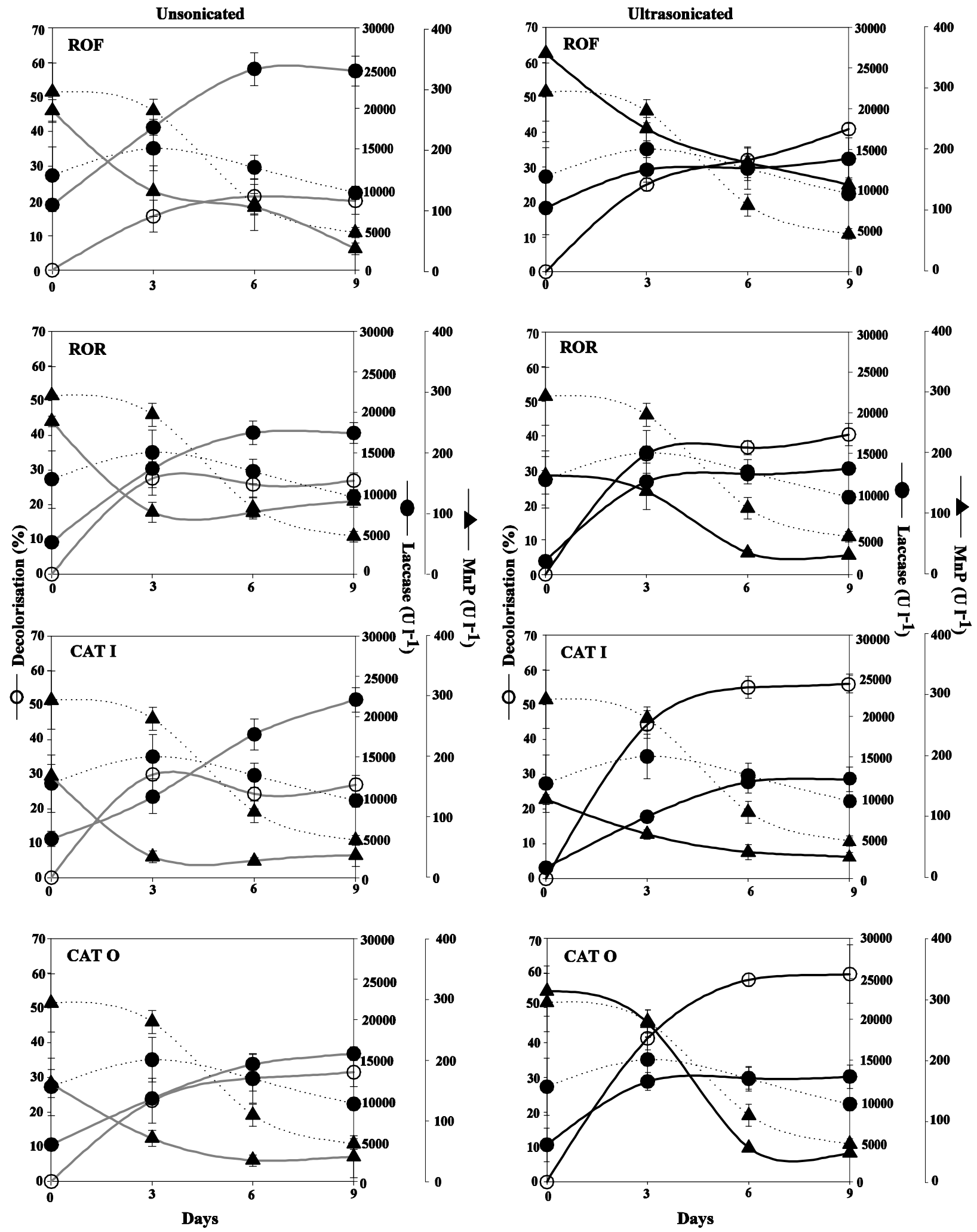

Fig. 2

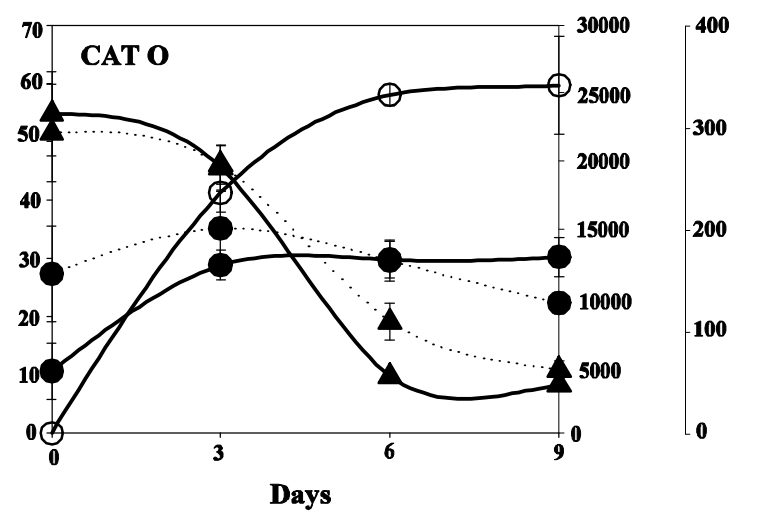



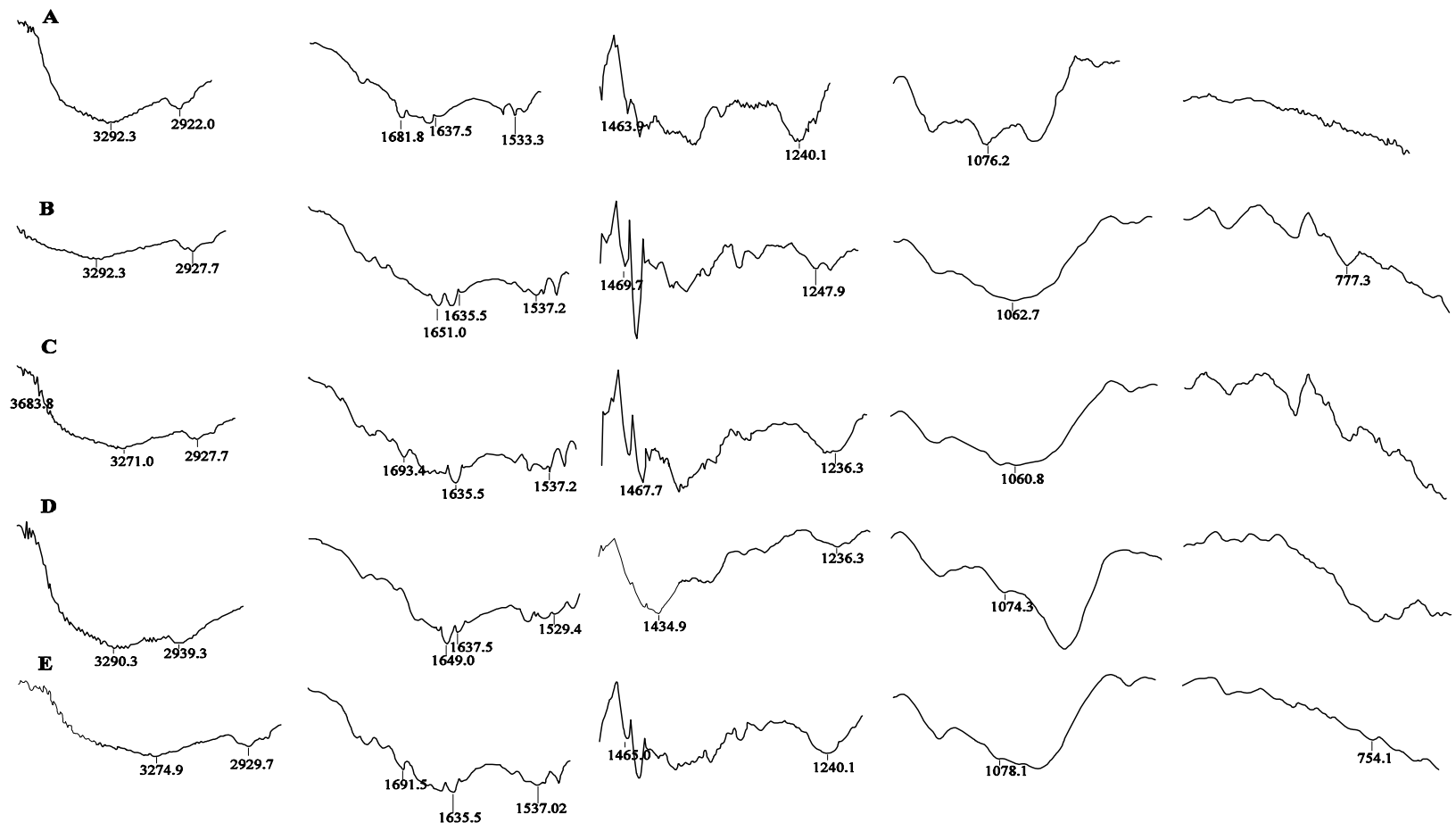

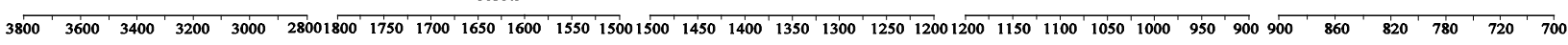
Supplementary Fig. 1 
A
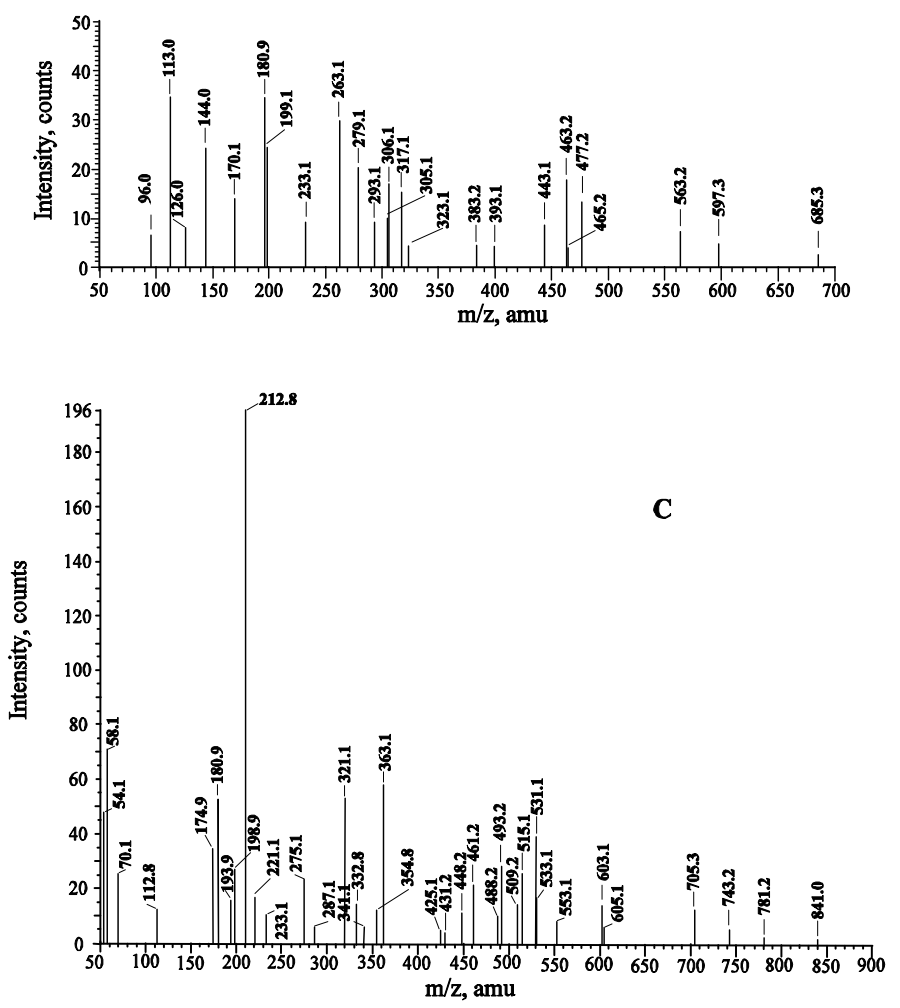
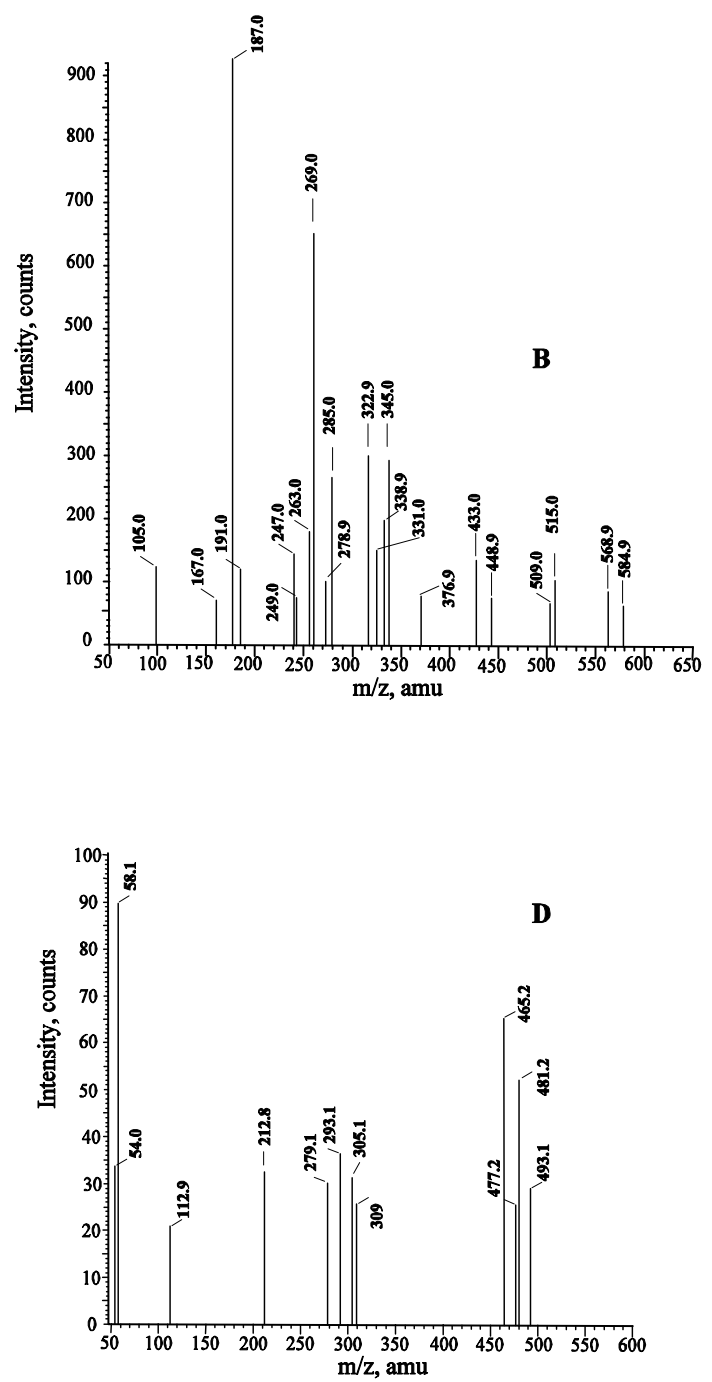

Supplementary Fig. 2 

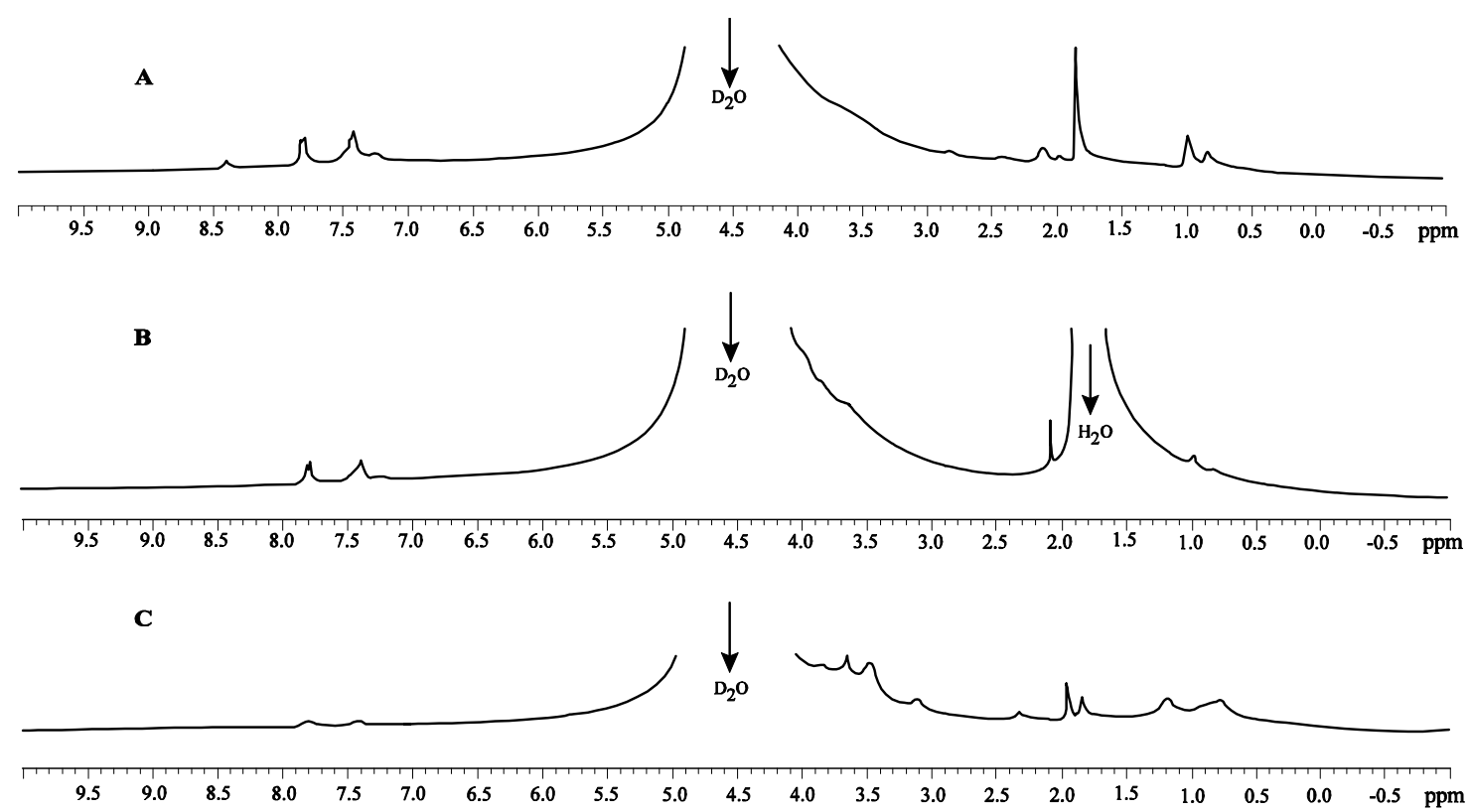

D

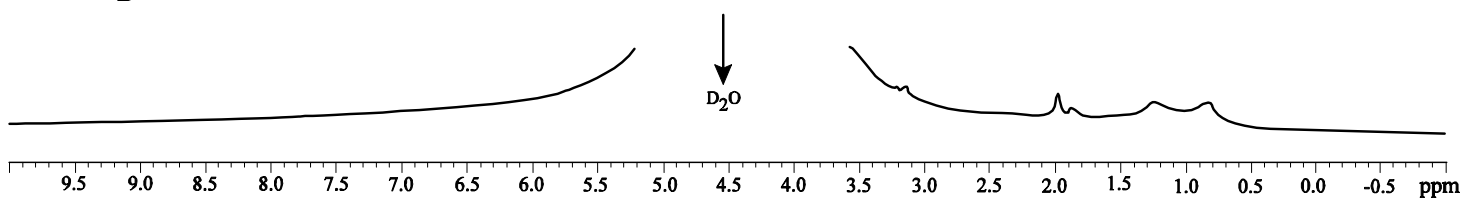

Supplementary Fig. 3 